\title{
Yol İnşaatı Şantiyelerinde Ergonomik Risk Değerlendirmesi
}

\author{
Kerim Yürek $^{1}$, İrem Ersöz Kaya ${ }^{2}$ \\ 1 Tarsus Üniversitesi, Lisansüstü Eğitim Enstitüsü, İş Sağlığı ve Güvenliği Anabilim Dalı, Tarsus, Mersin, Türkiye \\ 2 Tarsus Üniversitesi, Teknoloji Fakültesi, Yazılım Mühendisliği Bölümü, Tarsus, Mersin, Türkiye
}

(İlk Geliş Tarihi 1 Aralık 2019 ve Kabul Tarihi 31 Aralık 2019)

(DOI: 10.31590/ejosat.667469)

ATIF/REFERENCE: Yürek, K., \& Ersöz Kaya, İ. (2019). Yol İnşaatı Şantiyelerinde Ergonomik Risk Değerlendirmesi. Avrupa Bilim ve Teknoloji Dergisi, (17), 1357-1366.

\section{$\ddot{O} \mathbf{z}$}

Yol inşaatı şantiyeleri, aynı anda birden fazla riski bir arada bulunduran çalışma alanlarının başında yer almaktadır. Bu çalışmanın amacı yol inşaatı şantiyelerinde iş̧̧ilerin fiziki ve psikolojik özelliklerine uygun şekilde çalışma şartlarının sağlanması, iş̧ilerin sağlığının korunması ve şantiyede meydana gelebilecek iş kazaları riskinin minimum düzeye indirilmesi bakımından ergonomik risk değerlendirmesinin önemini vurgulamaktır. Ergonomik risk değerlendirmesi için yol inşaatı şantiyelerinde, yol yapım ince işlerden yol çizgisi yapım işi çalışanları seçilmiştir. Çalışanların pozisyon ve yaptıkları işler üzerinden ergonomik açıdan risk etmeni oluşturan duruş, kuvvet, tekrarlama ve süreklilik gibi farklı durumları içeren işler ele alınmıştır. Daha sonra yol çizgi çalışması yapılan şantiye alanı incelenmiş ve yapılan işlere ergonomik risk değerlendirmesi yapılmıştır. Ergonomik risk değerlendirmesinde OWAS, REBA ve ManTRA yöntemleri kullanılmıştır. Yapılan ergonomik risk değerlendirmesi sonucunda, yol çizgi çalışma ekibinde kas iskelet sisteminde zorlamaya neden olan işler tespit edilmiştir. Çalışmada ayrıca, yöntemlerin birbirlerine ve işlere göre karşılaştırılması ortaya konulmuştur. İncelenen işlerden birkaç tanesi dışında diğer tüm işlerde yakın zamanda iyileştirme yapılması gerektiği sonucuna ulaşılmıştır. Bu işlerde vücudun en çok zorlanan sırt bölgelerinde kas iskelet sistemi rahatsızlığına neden olacak durumlar sunulmuştur. ManTRA yönteminin vücut bölümleri ile ilgili ayrıntılı değerlendirme sonuçları sağladığı, yapılan işin öncelik bakımından düzenleme yapılıp yapılmayacağı konusunda tek başına yeterli olmadığı ama diğer risk değerlendirme yöntemleri ile birlikte kullanıldığında işin risk düzeyini desteklediği görülmüştür. Risk değerlendirmesinin temel amacına uygun olarak eylem seviyesi açısından en iyi sonuç OWAS ve REBA yöntemleri ile elde edilmiştir. OWAS veya REBA yöntemleri ile elde edilen eylem seviyesi ile birlikte ManTRA yönteminden elde edilen işlem önceliği birlikte kullanılarak vücudun odaklanılması gereken bölümü belirlenmiştir. Ergonomik risk değerlendirmesi sonucunda, çalışan ile kullanılan uygun makine-araç arasındaki önem ortaya koyulmuştur.

Anahtar Kelimeler: Yol İnşaatı Şantiyeleri, Ergonomik Risk Değerlendirmesi, İş Sağlı̆̆ı ve Güvenliği, OWAS, REBA, ManTRA.

\section{Ergonomic Risk Evaluation on Road Construction Sites}

\begin{abstract}
Road construction sites take place on the top of the fields which comprise more than one risk at the same time. The aim of this study is to lay emphasis on the evaluation of ergonomic risk in terms of providing working conditions in compliance with their physical and psychological characteristics, protecting workers' health and minimizing the risk of working accidents that may occur on construction sites. For ergonomic risk evaluation, making road line employees have been chosen for road construction craftmanship on the road construction sites. It has been discussed about the subjects including workers' position and different situations such as their stance,
\end{abstract}

${ }^{2}$ Sorumlu Yazar: Tarsus Üniversitesi, Teknoloji Fakültesi, Yazılım Mühendisliği Bölümü, Mersin, Türkiye, iremer@tarsus.edu.tr 
strength, repeatition that have risk agent ergonomically. Later on, road construction site that road line work had been done was analyzed and ergonomic risk evaultion was made for the work done. OWAS, REBA and ManTRA methods were used for the ergonomic risk evaluation. As a result of this ergonomic risk evaluation, some works have been detected that caused difficulties on road line workers' musculoskeletal systems. In the study, comparison of the methods according to each other and work was also made. It has been achieved that in all other works other than a few of the examined works, improvement is needed in the near future. In these jobs, the most difficult areas of the back muscles of the system will be presented to the cause of the situation. It has been found that the ManTRA method provides detailed assessment results on body parts, the work done is not sufficient in terms of prioritization, but it is supported by the risk level when used in conjunction with other risk assessment methods. In accordance with the main objective of the risk assessment, the best results in terms of level of action were obtained with OWAS and REBA methods. The action level obtained by the OWAS or REBA method together with the treatment priority obtained from the ManTRA method were used together to determine the fraction of the body to be focused. As a result of this ergonomic risk evaluation, the importance between the employees and suitable equipment used has been revealed.

Keywords: Road Construction Sites, Ergonomic Risk Evaluation, Occupational Health and Safety, OWAS, REBA, ManTRA.

\section{Giriș}

Ülkelerin ve toplumların gelişmesine paralel olarak ulaşım araçlarının yoğunluğu ve bunun sonucu olarak yol yapım gereksiniminin sürekli olarak artış gösterdiği bilinen bir gerçektir. Yol inşaatı şantiyelerinde işçilerin fiziki ve psikolojik özelliklerine uygun şekilde çalışma şartlarının sağlanması, işçilerin sağlığının korunması ve şantiyede meydana gelebilecek iş kazaları riskinin minimum düzeye indirilmesi bakımından çok önemlidir. Yol inşaatı şantiyelerinde meydana gelen iş kazalarını en aza indirmenin farklı metotları olmakla beraber, bahsedilen iş kazalarında insan faktörü göz ardı edilmemelidir.

Çalışma hayatının her alanında çalışma verimliliğinden ve işçi güvenliğine kadar uzanan sektörde, insan etkeni konusunda sürekli çalışmalar yapılmaktadır. Yol inşaatı şantiyelerinde, insan gücünün kullanımı ile verimliliğin yükselmesine paralel olarak, iş sağlı̆̆ı ve güvenliği uygulamalarının önem kazanmasını sağlayan bu çalışmalar, inşaat sektöründe ergonomik yaklaşımın zorunluluğunu ortaya çıkarmaktadır. Ergonomi; insanların anatomik özelliklerini, antropometrik karakteristiklerini, fizyolojik kapasite ve toleranslarını göz önünde tutarak, endüstriyel iş ortamındaki tüm faktörlerin etkisiyle oluşabilecek organik ve psiko-sosyal stresler altında, sistem verimliliğini ve insan-makine-çevre uyumunun temel yasalarını ortaya koymaya çalışan çok disiplinli bir bilim dalıdır. Diğger bir deyişle, insanı çeşitli açılardan inceleyen ve katlanabileceği sınırları tespit eden, işin insana ve insanın işe uyumluluğunu araştıran, disiplinlerarası bir alandır (Erkan, 1997).

Günümüzde hızla gelişen teknoloji çalışma yaşamında bazı değişikliklere neden olmaktadır. Bu değişikler çalışan insanın yeteneklerini ve çalışma şartlarını zorlamaktadır. Çalışanların üretim sürecinde makinler ile birlikte yürütülen işler, insan yeteneklerini kısıtlamakta ve çalışanları bedensel ve ruhsal olarak yıpratmaktadır. Bu nedenle, iş yerinde çalışanların yapması beklenen işler ile insanın yetenek ve yapısına uygun işler arasında bir denge sağlanması gerekmektedir. İş yerinde verimli ve güvenli bir çalışma ortamının sağlanması için ses, aydınlatma, sıcaklık gibi faktörler, çalışanın yapısına ve psikolojisine uygun olarak düzenlenmiş olmalıdır. Bu yöndeki düzenlemeler ergonomi biliminin temel görevidir. Daha açık bir şekilde, iş insan özelliklerine göre düzenlenmeli ve insanlara uygun işler tasarlanarak çalışanların yaşam standartları yükseltilmelidir.

İş kazaları ve meslek hastalıkları ile iş aktivitelerine bağlı olarak ortaya çıkan veya seyri şiddetlenen sağlık sorunlarının nedenlerini araştırma ve koruma yöntemleri geliştirerek bu zararlı unsurları çalışma ortamından uzaklaştırmak için risk değerlendirmesi öncelikli gerçekleştirilmesi gereken unsurlardan biridir. Risk değerlendirmesi, mevcut bulunan tehlikelerden kaynaklanabilecek risklerin göreceli önem derecesini ortaya çıkarmak için yapılan bir iştir. Ardından, önleyici etkin yöntemlerden başlayarak kontrollerin de tasarlanması gerekir. Önleme ve kontrol faaliyetleri için hangi öncelikleri gözeterek ne kadar zaman ayrılması gerektiği ve hangi kaynakların tahsis edileceği belirlenir ve zararlı etkiler değerlendirilerek derecelendirilir. Katlanılabilir olanlarla acilen ortadan kaldırılması veya katlanılabilir düzeylere kadar azaltılması gerekli olan zararlı etkenleri ayıklamak için bir değerlendirmeye ihtiyaç bulunmaktadır.

Literatürde, iş sağlı̆̆ı ve güvenliği alanında iş kazalarına sebep olan faktörlerin belirlenmesi ve bu konuda alınması gereken önlemlerin tasarlanması üzerine birçok çalışma yer almaktadır. Örneğin Aksöyek (2002), inşaat sektöründe son 10 yılda meydana gelen iş kazalarını inceleyerek, kazalara neden olan faktörlerin saptamış, kazalardan korunmak için gerekli uygulamaların belirlemiş ve iş güvenliği açısından, inşaat sektörünü değerlendirmiş ve iyileştirici öneriler sunmuştur. Başka bir çalışmada Müngen (2011), inşaat sektöründe en çok rastlanan iş kazası tiplerinin neler olduğunu açıklamış, bazı önemli kaza tiplerinin alt ayrımları ve yine önemli şantiye türlerinde ön plana çıkan kaza tiplerini sayısal verilerle tanıtmıştır. Yol yapım şantiyelerinde uygulanan iş sağlığı ve güvenliği düzenlemelerine ilişkin bir çalışmada ise yol yapım, bakım ve onarım şantiyeleri ile çevresel etkiler incelenmiştir. Sahada görev alan çalışanlar ile görüşmeler yapılarak, şantiyedeki iş sağlığ sahada karşılaşılabilecek tehlike ve risk durumları belirlenmiştir. Bu tehlike ve risk durumlarını oluşmadan önlemek, iş kazalarını ve meslek hastalıklarını en aza indirmeye yardımcı olacak her şantiyeye özgü kontrol listeleri ortaya çıkarılmıştır (Gönenç, 2016).

İş kazaları ve meslek hastalıklarının ortaya çıkmasında etkili faktörler arasında yer alan ergonomi konusunda yapılan çalıșmalar da literatürde önemli bir yer tutmaktadır. Özcan ve Kesiktaş (2007), meslek kas iskelet hastalıklarından korunma konusunda ergonomik programların etkinliğine değinmişlerdir. Benzer şekilde, Kuruoğlu vd. (2015) ergonomi ve antropometri bilim dallarına ait temel bilgilere değinerek, inşaat sektöründe iş sağlığı ve güvenliği açısından ergonomik ve antropometrik tasarımın önemi vurgulamışlardır. 
Bununla birlikte, ergonomik risk faktörlerinin araştırıldığı diğer bir çalışmada, ergonomik risk değerlendirme yöntemlerinden yararlanılarak ortaya çıkabilecek kas iskelet sistemi rahatsızlıkları konusundaki riskler belirlenmiştir (Atasoy Mert, 2014). Fiziksel güç gerektiren işlerde çalışanlarda sırt, bacak, kol, boyun, vb. bölgelerde sıklıkla görülen kas iskelet sistemi rahatsızlıklarınının ele alındığı bir başka çalışmada da ergonomik risk değerlendirme yönetemlerine ve işe bağlı kas-iskelete sistemi sorunlarına yer verilmiştir (Koç ve Testik, 2016)

Yapılan çalışmalardan da görüldüğü üzere, işçi sağlığı ve iş güvenliğinde risk analizi ve ergonomik faktörlerin etkisi, önemli ve acil önemler alınması gereken bir sorun olarak ortaya çıkmaktadır. Her gün inşaat sektörü başta olmak üzere çok sayıda çalışan, engellenmesi mümkün ve yasalar ile de engellenmesi şart olan iş kazaları ve meslek hastalıkları yüzünden ölmekte veya bu iş kazasının sonuçlarını hayatı boyunca çekmeye maruz bırakılmaktadır. Bu kazaların en fazla meydana geldiği inşaat sektörü içinde yol inşaatı şantiyeleri ise bu alanda ilk sıralarda yer almaktadır. Bu çalışmada yol inşaatı şantiyelerinde ince işlerden yol çizgi işi yapımında, olumsuz çalışma koşullarının kaldırılmasına yönelik bir bakış açısı ile ergonomik risk değerlendirmesi yapılacaktır. Çalışma ortamının insanın fizyolojik ve psikolojik yapısına uygun olarak düzenlenmesi esas alınacak, bu konuda psikolojik yönünden çok çalışma ortamındaki fiziksel şartlar üzerinde durulacaktır.

\section{Materyal ve Metot}

Çalışmanın ilk aşamasında ergonomik risk değerlendirilmesinde ihtiyaç duyulacak ilgili tüm bilgiler toplanarak değerlendirilmiş ve yol inşaatı şantiyesinde yerinde gözle muayene yapılmıştır. Ardından, ergonomik risk değerlendirmesi yapılacak olan işler belirlenmiştir (Tablo 1). Bu işlem yapılırken şantiye sahasına girişten itibaren yapılan tüm işler ele alınarak listeleme yapılmıştır.

Tablo 1. Ergonomik Risk Değerlendirmesinde Uygulanan İsler

\begin{tabular}{|c|c|}
\hline İş No & Uygulanan İş \\
\hline İş 1 & İkmal yapılacak boya tenekesinin istif yerinden indirilmesi \\
\hline İş 2 & İndirilen boya tenekesinin dolum yerine getirilmesi \\
\hline İş 3 & Dolum yapılacak tenekenin ağzının spatula ile açılması \\
\hline İş 4 & Ağzı açılan tenekedeki boyanın mikser ile karıştırılması \\
\hline İş 5 & Mikser ile karıştırılan boyanın ikmal kazanına dökülmesi \\
\hline İş 6 & Cam küreciklerinin istif yerinden indirilmesi \\
\hline İş 7 & İndirilen cam küreciklerinin dolum yerine getirilmesi \\
\hline İş 8 & Dolum yerine getirilen cam küreciği çuvallarının maket bıçağı ile ağzının açılması \\
\hline İş 9 & Ağzı açılan cam küreciği çuvallarının çizgi arabasına dökülmesi \\
\hline İş 10 & Çizgi arka operatörünün çizgi aparat direksiyonu ile açma-kapama yapması \\
\hline İş 11 & Çizgi ön operatörünün çizgi arabasını sürmesi \\
\hline İş 12 & Yol çizgi işi yapıldıktan hemen sonra konilerin yola dizilmesi \\
\hline İ̀s 13 & Yol çizgi işi yapıldıktan hemen sonra konilerin geri toplanması \\
\hline
\end{tabular}

Ergonomik risk değerlendirmesi için geliştirilmiş birçok metot bulunmaktadır (Yürek, 2018). Yol çizgi işi çalışanlarının pozisyon ve yaptıkları işler göz önüne alındığında, ergonomik açıdan risk etmeni oluşturan duruş, kuvvet, tekrarlama ve süreklilik gibi farklı bileşenleri değerlendirmeye alan, ManTRA (Manual Tasks Risk Assessment Tool-Elle Yapılan Görevler için Risk Değerlendirme Aracı), OWAS (Ovako Working Posture Analyzing System-Ovako Çalı̧sma Duruşları Analiz Sistemi) ve REBA (Rapid Entire Body Assessment-Hızlı Tüm Vücut Değerlendirmesi) gibi yöntemler tercih edilmiştir. Bu metodların uygulanması sonucunda, yol inşaatı şantiyelerinde çalışanlar üzerindeki ergonomik riskler ve alınacak önlemler belirlenmiş; yöntemlerin birbirlerine karşı olan üstünlükleri karşılaştırılarak iş tiplerine göre uygunlukları tartışılmıştır.

\subsection{OWAS}

OWAS, çalışanların kas-iskelet sistemindeki zorlanmaları ve sistemden kaynaklı kötü çalışma duruşlarını belirlemeye yarayan gözleme dayalı bir analiz metodudur. OWAS metodu, iş etüt yapanlara iş yerindeki çalışma metotlarının iyileştirilmesinde gerekli düzenlemelerin yapılmasına yardımcı olması amacıyla tasarlanmıştır. Temeli ise çalışma duruşlarının örneklenmesine dayanmaktadır (Corlett vd., 1986). Finlandiya'da bulunan bir çelik üretim şirketi (Ovako) tarafindan 1970 ortalarında geliştirilmiştir.

OWAS yöntemi, çalışanın sırt duruşu, bacak duruşu ve kol duruşlarını değerlendirir. OWAS; 4 sırt duruşu, 7 bacak duruşu, 3 kol duruşuyla kaldırılan yük ağırlı̆ı̆ını değerlendiren üç yük durumu kombinasyonundan meydana gelen toplamda $252(4 \times 3 \times 7 \times 3)$ adet duruş ve yük kombinasyonuna sahiptir. Bu metoda göre, ergonomik risk değerlendirmesini yapan kişi, çalışanların yapmakta olduğu görev sırasında gözlemleyerek sırt duruşları, kol duruşları ve bacak duruşları ile beraber vücut duruşlarını ve çalışanların iş boyunca uyguladığı yükü 4 dijital kod yardımı ile kayıt eder (Akay ve Dağdeviren, 2003). İkinci aşamada ise çalışanların yaptığı her bir vücut duruşu için geçen süre ve duruşun gerçekleşme aralığı analiz edilir. Analizi yapan kişi vücut duruşlarını kayıt altına alır. Yapılan bu kayıtlar analiz edilen iş için farklı zamanlarda tekrar edilir. 


\subsection{ManTRA}

Yöntem, çalışanın işi yaptığı normal bir günündeki toplam zamanı ve ara vermeden işin yapıldığı normal zamanı değerlendirerek; çevrim zamanı, kuvvet, hız, uygunsuzluk ve titreşim bileşenlerini kullanır. Vücudun 4 vücut bölgesi ve görevin 5 özelliği ile ilgili bilgiler birleştirilerek bir değerlendirme yapılır. ManTRA yönteminde kullanılan kodlar, toplam zaman, tekrarlama, süre, çevrim zamanı, tekrarlama risk faktörü, kuvvet, hız, çaba risk faktörü, uygunsuzluk ve titreşim (tüm vücut veya çevresel) olarak verilmektedir (Limerick, 2016; Yürek, 2018).

- Toplam zaman: Normal bir iş gününde işin yapılması için geçen toplam zamanı ifade etmektedir. Vücudun her bir bölgesi için kod aynidir.

- Tekrarlama: Yapılan işlerin çevrim zamanının kısa olması ve uzun süre yapılması risk faktörü olarak ele alınır; çünkü iş yapıldığ1 zaman boyunca kaçınılmaksızın aynı noktaya yüklenme yapılır. Çevrim süresi dikkate alınmaksızın, aralıksız çok uzun süre yapılan işlerde ( 2 saatten fazla) aynı şekilde risk vardır. Az risk, kısa iş süresi ve uzun çevrim zamanlı işlerle ilişkilendirilir. Çevrim zamanı ve işin süresi birbirinden bağımsız olarak ele alınır. Sonrasında tekrarlama risk faktörü için birleştirilmiş puan kullanılır.

- Süre: Dinlenme arası veya farklı bir işle önemli bir kesinti olmadan, yapılan işteki tekrarlamaların olduğu zamanın normal uzunluğu olarak tanımlanmaktadır.

- Çevrim zamanı: Aralıksız olarak birden çok yapılan iş süresidir. Çevrim zamanı kodu vücut bölümlerinde farklı olarak görülmektedir. Eğer iş tekrarlama olmadan herhangi bir zamanda bir kere yapılıyorsa, çevrim zamanı kodu 1 olarak ele alınır.

- Tekraralama risk faktörü: Tekrarlama kodu belli bir işte bütün vücut bölgeleri için aynı kabul edilir. Tekrarlama toplam puanı için çevrim zamanı ve süre kodları birleştirilerek alınır.

- Kuvvet: En çok harcanan çabaya göre, vücudun her bir bölgesinin harcadığı kuvvet değerlendirmeye alınır. Değerlendirme, mutlak kuvvete göre değil, bölgenin güç yeteneğine göre yapılır. Kuvvetin değerlendirilmesi, işi yapan kişiye göre farklılık gösterir. İhtiyaç olan kuvvet için, çabanın süresinden bağımsız olarak puanlama yapılır.

- Hız: Yapılan işin yavaş ve orta derecede hareketlerden oluşması risk seviyesini minimuma indirmektedir. Bölgede statik kuvvet uygulayan işler kas iskelet yaralanmalarına neden olmaktadır. Bununla birlikte, hızlı hareket, hızlı ivmelenme ve yavaşlama yüksek risk oluşturmaktadır. Değerlendirme yapılırken tüm işi kapsayacak şekilde, bazı hızlı hareketler olsa da genellikle yavaş hareketleri içeren işler, orta hızlı hareket olarak değerlendirmeye alınır.

- Çaba risk faktörü: Kuvvet ve hız kodlarının birleştirilmesiyle çaba risk faktörü puanlaması elde edilir.

- Uygunsuzluk: Uygunsuzluğun tek başına değerlendirilmesi çok zordur. Ama genellikle hareketin normal durumundan önemli sapmalar meydana geldiği duruşlarda yaralanma riski artmaktadır. Değerlendirme yapılırken, iş bir bütün halinde ele alınır ve uygunsuz duruşta geçen sürenin oranı yansıtılacak biçimde düzenlenir. Çalışanın vücut duruşuna göre belirlenen sırt, boyun/omuzlar, kol/bilek/el ve bacak bölgeleri uygun şekilde kodlanır.

- Tireşim: Diğer risk faktörlerine ek olarak tüm vücut titreşimine uğramak; özellikle sırt, bel ve alt kısım yaralanma riski oranını arttırmaktadır. Ayrıca çevresel titreşim, üst kısım rahatsızlıkların ilk risk faktörüdür. Neticede; alt kısım, sırt ve boyun bölgeleri için tüm vücut titreşimine şiddet; omuz/kol ve bilek/el bölgeleri için evrensel titreşimin şiddeti ele alınır. Tüm işin puanlaması, maruz kalınan zamanın iş içerisindeki oranına göre yapılır.

Uygulamada, yukarıda verilen kodlardan elde edilen puanlar toplanarak birikimli risk faktörü ve birikimli risk puanı elde edilir. Birikimli risk puanı 5-25 puan arasinda yer alır.

\subsection{REBA}

REBA yöntemi, Hignett ve McAtamney (2000) tarafından vücut duruşlarını değerlendirmek üzere geliştirilmiştir. Elle yapılan kaldırma, taşıma işlerindeki riskleri değerlendirmede kullanılan ve olumlu sonuçlar veren bir yöntemdir. REBA yöntemi ile dinamik hareketlerden başka statik duruşlarda da değerlendirme yapılabilmektedir (Kocabeş, 2009). Bu sayede, çalışanın vücut duruşuna ilgili riskler daha kapsamlı olarak REBA yöntemi ile değerlendirme imkanı sağlanmaktadır (Stanton vd., 2005).

REBA yönteminde gözlemlenen duruşlar genel olarak iki sınıfta toplanarak değerlendirilmektedir. Grup A olarak adlandırılan gövde, boyun ve bacak duruş/hareketlerini, Grub B'de ise üst kollar, alt kollar ve bilek duruş/hareketlerini içermektedir. Duruş/hareketlerin şekillerinden elde edilen veriler ile ilgili tablolar kullanılarak grup bazında vücut bölümlerinin puanlaması elde edilir (Yürek, 2018). Duruş/hareket şekillerinde yer alan fleksiyon hareketinde bükülme veya eklem açısının küçülmesi, ekstansiyonda ise gerilme ya da eklem açısının büyümesi söz konusudur.

\section{Araştırma Sonuçları ve Tartışma}

Yol inşaatı şantiyelerinde ergonomik risk değerlendirmesi yol ince işlerini yapan yol çizgi ekibinde uygunlanmıştır. Çalışmanın amacına uygun olarak ilk önce yol çizgi işinde mevcut risk durumları incelenmiş ve bu risk durumlarına öngörülen ergonomik risk değerlendirme yöntemleri seçilmiştir. Daha sonra yol çizgi çalışması yapılan şantiye alanı incelenmiş ve yapılan işlere ergonomik risk değerlendirmesi yapılmıştır. Ergonomik risk yöntemleri uygulanırken duruş, kuvvet, tekrarlama ve süreklilik risk faktörlerinin farklı bileşimi kullanılarak her bir yöntemin işlere olan duyarlılıkları belirlenmiştir. Şantiyede kas iskelet sistemi rahatsızlığı oluşumuna neden olabilecek işler, ergonomik risk değerlendirmesi sonucu ortaya çıkmıştır.

Yöntemlerden elde edilen verilerin karşılaştırılması amacıyla, yöntemlerde mümkün olan en büyük sonuç puanı ile elde edilen sonuç puanı kullanılarak risk yüzdesine dönüştürülmüştür. Ergonomik risk değerlendirmesi yüzdesini belirlemek için Tablo 2 kullanılmıştır. 
Tablo 2. Örnek Ergonomik Risk Değerlendirmesi Risk Yüzdesi Belirleme

\begin{tabular}{cccc}
\hline Yöntem & Elde Edilen Sonuç & Mümkün En Büyük Sonuç & Risk Yüzdesi \\
\hline OWAS & 2 & 4 & $\% 50$ \\
REBA & 8 & 15 & $\% 53$ \\
ManTRA & 3 & 5 & $\% 60$ \\
\hline
\end{tabular}

OWAS ve REBA yöntemlerinde mümkün en büyük sonuç sabit bir değer iken, ManTRA yönteminde mümkün en büyük sonuç değişmektedir. ManTRA yönteminde elde edilen çaba risk faktörü, çaba risk faktörü+uygunsuzluk ve birikimli risk puanlarından hangisinin değeri ve risk yüzdesi yüksek, düzenleme gerekli olup olmadığı o risk yüzdesine göre karar verilir.

Yöntemlerin sonuçlarından elde edilen verilerin karşılaştırılması ve böylece hangi risk faktörlerinin duyarlılıklarının belirlenmesi amacıyla her bir iş için aşağıdaki tablolar oluşturulmuştur.

Tablo 3. İş 1 İçin Yapılan Ergonomik Risk Değerlendirmesi Sonucu

\begin{tabular}{|c|c|c|}
\hline İşin Adı & İkmal Yapılacak Boya Tenekesinin İstif Yerinden İndirilmesi & \\
\hline Yöntemin Adı & Değerlendirme Sonucu & Risk Yüzdesi \\
\hline OWAS & $\begin{array}{c}\text { Çalışanın kas iskelet sistemine zararlı etkilere neden olan bir durumda olduğu için } \\
\text { düzenleme en kısa zamanda yapılmalıdır. }\end{array}$ & $\% 75$ \\
\hline REBA & $\begin{array}{c}\begin{array}{c}\text { Risk düzeyi yüksek olarak çıkmaktadır ve yakın zamanda bu iş için iyileştirme } \\
\text { gerektirmektedir. }\end{array}\end{array}$ & $\% 53$ \\
\hline ManTRA & $\begin{array}{c}\text { Sırt, boyun/omuzlar, kol/bilek/el ve bacak bölgeleri için düzenleyici işlem } \\
\text { önceliği mevcuttur }\end{array}$ & $\% 100$ \\
\hline
\end{tabular}

Tablo 3 incelendiğinde ikmal yapılacak boya tenekesinin istif yerinden indirilmesi işinde risk yüzdesi bakımından en yüksek sonucun ManTRA yöntemi ile elde edildiği görülmektedir. Çaba risk faktörü 5 olarak hesaplandığı için risk yüzdesi en yüksek değeri vermektedir. ManTRA yöntemine göre kol/bilek/el bölgeleri için düzenleyici işlem önceliği mevcuttur sonucu elde edilmiştir. OWAS yöntemi ikinci olarak en yüksek risk yüzdesini vermektedir ve bu sonuca göre çalışanın kas iskelet sistemine zararlı etkilere neden olan bir durum olduğu için en kısa zamanda düzenleme yapılması gerektiği sonucuna ulaşılmıştır. REBA yöntemi sonu risk yüzdesi bakımında son sırada yer almaktadır. Fakat eylem önceliği bakımından risk düzeyi yüksek çıktığı için yakın bir zamanda ikmal yapılacak boya tenekesinin istif yerinden indirilmesi işi için iyileştirme gereklidir sonucunu vermektedir. Tüm yöntemlerden elde edilen sonuçlara bakılarak ikmal yapılacak boya tenekesinin istif yerinden indirilmesi işi çalışanın kas iskelet sistemine zararlı etkilere neden olmaktadır. Sonuç olarak, çalışanın sırt, boyun/omuz ve kol/bilek/el bölgelerinde yakın bir zamanda düzenleyici işlem yapılması gerektiği tespit edilmiştir.

Tablo 4. İş 2 İçin Yapılan Ergonomik Risk Değerlendirmesi Sonucu

\begin{tabular}{|c|c|c|}
\hline İşin Adı & İndirilen Boya Tenekesinin Dolum Yerine Getirilmesi İşi & \\
\hline Yöntemin Adı & Değerlendirme Sonucu & Risk Yüzdesi \\
\hline OWAS & $\begin{array}{l}\text { Çalışanın kas iskelet sistemine zararlı etkilere neden olan bir durumda olmadığ } 1 \\
\text { için düzenleme gerekli değildir. }\end{array}$ & $\% 25$ \\
\hline REBA & Risk düzeyi orta olarak çıkmaktadır ve bu iş için iyileştirme gereklidir. & $\% 26$ \\
\hline ManTRA & $\begin{array}{c}\text { Sırt, boyun/omuzlar ve kol/bilek/el bölgelerinde düzenleyici işlem önceliği } \\
\text { mevcuttur. }\end{array}$ & $\% 66$ \\
\hline
\end{tabular}

Boya tenekesinin dolum yerine getirilmesi işinde risk yüzdesi bakımından en iyi sonuç ManTRA yöntemiyle elde edilmiştir. Birikimli risk puanı 10 olarak hesaplanmıştır (Tablo 4). Bu sonuca göre düzenleyici işlem önceliği bulunduğu sonucu elde edilmiştir. Fakat eylem seviyesi açısından incelendiğinde ise REBA yönteminde risk düzeyi orta ve iyileştirme yapılması gereklidir sonucunu vermektedir. OWAS yöntemi açısından bakıldığında risk yüzdesi ikinci sırada ve çalışanın kas iskelet sistemine zararlı etkilere neden olan bir durum olmadığı sonucuna ulaşılmıştır. Tüm yöntemlerden elde edilen sonuçlar incelendiğinde indirilen boya tenekesinin dolum yerine getirilmesi işinde vücut bölümlerinden sırt, boyun/omuzlar ve kol/bilek/el bölgesi etkilenmekte olup bu iş için iyileştirme gerektiği belirlenmiştir.

Tablo 5. İş 3 İçin Yapılan Ergonomik Risk Değerlendirmesi Sonucu

\begin{tabular}{|c|c|c|}
\hline İşin Adı & Dolum Yapılacak Tenekenin Ağzının Spatula İle Açılması İşi & \\
\hline Yöntemin Adı & Değerlendirme Sonucu & Risk Yüzdesi \\
\hline OWAS & $\begin{array}{c}\text { Çalışanın kas iskelet sistemine zararlı etkilere neden olan bir durumda olduğu için } \\
\text { düzenleme en kısa zamanda yapılmalıdır. }\end{array}$ & $\% 75$ \\
\hline REBA & $\begin{array}{l}\text { Risk düzeyi orta olarak çıkmaktadır. Bu sonuca göre bu iş için iyileştirme } \\
\text { gereklidir. }\end{array}$ & $\% 33$ \\
\hline ManTRA & Düzenleyici işlem önceliği yoktur. & $\% 53$ \\
\hline
\end{tabular}

Tablo 5 incelendiğinde dolum yapılacak tenekenin ağzının spatula ile açılması işinde risk yüzdesi bakımında OWAS yöntemi en yüksek değeri vermektedir. Eylem önceliği bakımından incelendiğinde OWAS yöntemi sonucuna göre çalışanın kas iskelet sistemine zararlı etkilere neden olan bir durumda olduğu için düzenleme en kısa zamanda yapılmalıdır. REBA yöntemi sonucu incelendiğinde e-ISSN: 2148-2683 
risk yüzdesi düşük çıkmasına rağmen risk düzeyi orta çıkmıştır ve bu iş için iyileştirme gereklidir sonucu elde edilmiştir. ManTRA yöntemi risk yüzdesi ikinci sırada olmasına rağmen eylem düzeyi açısından işlem önceliği yoktur sonucunu vermiştir. Bu sonuç birikimli risk puanının 8 olarak hesaplanması sonucunda görülmüştür. Tüm yöntemler incelediğinde çalışanın kas iskelet sistemine zararlı etki eden durumların olduğu ve sırt, boyun/omuz kol/bilek/el ve bacak bölgelerinde yakın bir zamanda düzenleyici işlem yapılması gerektiği sonucuna ulaşılmıştır.

Tablo 6. Işs 4 İ̧̧in Yapılan Ergonomik Risk Değerlendirmesi Sonucu

\begin{tabular}{|c|c|c|}
\hline İşin Adı & Ağzı Açılan Tenekedeki Boyanın Mikser İle Karıştırılması İşi & \\
\hline Yöntemin Adı & Değerlendirme Sonucu & Risk Yüzdesi \\
\hline OWAS & $\begin{array}{c}\text { Çalışanın kas iskelet sistemine etki eden zorlanma durumu fazla değildir. } \\
\text { Düzenleme yakın bir zamanda yapılmalıdır. }\end{array}$ & $\% 50$ \\
\hline REBA & $\begin{array}{l}\text { Risk düzeyi orta olarak çıkmaktadır. Bu sonuca göre bu iş için iyileştirme } \\
\text { gereklidir. }\end{array}$ & $\% 33$ \\
\hline ManTRA & $\begin{array}{c}\begin{array}{l}\text { Sırt, boyun/omuzlar ve kol/bilek/el bölgesi için düzenleyici işlem önceliği } \\
\text { mevcuttur. }\end{array} \\
\end{array}$ & $\% 100$ \\
\hline
\end{tabular}

Ağzı açılan tenekedeki boyanın mikser ile karıştırılması işinde en büyük risk yüzdesi ManTRA yöntemiyle elde edilmiştir (Tablo 6). Birikimli risk puan 15 olarak hesaplanmıştır. ManTRA yöntemi ile elde edilen sonuca göre sırt, kol/omuzlar ve kol/bilek/el bölgesi için düzenleyici işlem önceliği mevcuttur. Eylem seviyesi açısından bakıldığında ise OWAS yönteminin sonucunda çalışanın kas iskelet sistemine etki eden zorlanma durumu fazla değildir ve düzenleme yakın bir zamanda yapılmalıdır. REBA yöntemi sonucunda ise risk düzeyi orta olarak çımaktadır ve bu sonuca göre iyileştirme gereklidir olarak elde edilmiştir. Bu iki yöntem de aynı sonucu vermektedir. Tüm yöntemler incelendiğinde ağzı açılan tenekedeki boyanın mikser ile karıştırılması işinde çalışanın kas iskelet sistemine etki eden zorlama durumları olduğu saptanmıştır. Çalışanın sırt, boyun/omuz ve kol/bilek/el bilek bölgelerinde yakın bir zamanda düzenleyici eylem gerekmektedir.

Tablo 7. Işs 5 İçin Yapılan Ergonomik Risk Değerlendirmesi Sonucu

\begin{tabular}{|c|c|c|}
\hline İşin Adı & Mikser İle Karıștırılan Boyanın İkmal Kazanına Dökülmesi İşi & \\
\hline Yöntemin Adı & Değerlendirme Sonucu & Risk Yüzdesi \\
\hline OWAS & $\begin{array}{l}\text { Çalışanın kas iskelet sistemine etki eden bir zorlanma durumu olmadığı için } \\
\text { düzenleme gerekli değildir. }\end{array}$ & $\% 25$ \\
\hline REBA & $\begin{array}{l}\text { Risk düzeyi orta olarak çıkmaktadır. Bu sonuca göre bu iş için iyileştirme } \\
\text { gereklidir. }\end{array}$ & $\% 27$ \\
\hline ManTRA & $\begin{array}{l}\text { Sirt, boyun/omuzlar ve kol/bilek/el bölgelerinde düzenleyici işlem önceliği } \\
\text { mevcuttur. }\end{array}$ & $\% 100$ \\
\hline
\end{tabular}

Tablo 7'deki veriler değerlendirildiğinde mikser ile karıştırılan boyanın ikmal kazanına dökülmesi işinde en büyük risk yüzdesi ManTRA yöntemi ile elde edilmiştir. Çaba risk faktörü 5 olarak hesaplanmıştır. ManTRA yöntemi elde edilen sonuca göre boyun/omuzlar ve kol/bilek/el bölgelerinde düzenleyici işlem önceliği mevcuttur. OWAS ve REBA yöntemleri ile elde edilen risk yüzdeleri aynıdır. Eylem seviyesi bakımında incelendiğinde OWAS yönteminde çalışanın kas iskelet sistemine etki eden bir zorlanma durumu olmadığı için düzenleme gerekli olmadığı sonucu elde edilirken, REBA yöntemi ile risk düzeyi orta olarak çıkmaktadır ve iyileştirme gereklidir sonucuna ulaşılmıştır. Tüm yöntemlerden elde edilen sonuçlar incelendiğinde çalışanın kas iskelet sistemine etki eden bir zorlanma durumu olmaktadır. Çalışanın sırt, boyun/omuzlar ve kol/bilek/el bölgelerinde düzenleyici eylem gerekmektedir.

Tablo 8. İş 6 İ̧̧in Yapılan Ergonomik Risk Değerlendirmesi Sonucu

\begin{tabular}{|c|c|c|}
\hline İşin Adı & Cam Küreciklerinin İstif Yerinden İndirilmesi & \\
\hline Yöntemin Adı & Değerlendirme Sonucu & Risk Yüzdesi \\
\hline OWAS & $\begin{array}{c}\text { Çalışanın kas iskelet sistemine etki eden bir zorlanma durumu olmadığ için } \\
\text { düzenleme gerekli değildir. }\end{array}$ & $\% 25$ \\
\hline REBA & $\begin{array}{l}\text { Risk düzeyi orta olarak çıkmaktadır. Bu sonuca göre bu iş için iyileştirme } \\
\text { gereklidir. }\end{array}$ & $\% 27$ \\
\hline ManTRA & Srrt ve kol/bilek/el bölgelerinde düzenleyici işlem önceliği mevcuttur. & $\% 100$ \\
\hline
\end{tabular}

Cam küreciklerinin istif yerinden indirilmesi işinde risk yüzdesi bakımından en iyi sonucu ManTRA yöntemi vermektedir (Tablo 8). Çaba risk faktörü puanı 5 olup çalışanın sırt ve kol/bilek/el bölgelerinde düzenleyici işlem önceliği mevcuttur sonucunu vermektedir. Risk yüzdesi bakımından OWAS ve REBA yöntemleri aynı sonucu vermektedir. Eylem seviyesi bakımından REBA yöntemi bu iş için iyileştirme gereklidir sonucunu verirken OWAS yöntemi düzenleme gerekli değildir sonucunu vermektedir. Tüm yöntemlerden elde edilen sonuçlar incelendiğinde ise çalışanın sırt ve kol/bilek/el bölgesinde düzenleyici işlem gerektiği sonucuna ulaşılmıştır. 
Tablo 9. İş 7 İçin Yapılan Ergonomik Risk Değerlendirmesi Sonucu

\begin{tabular}{|c|c|c|}
\hline İșin Adı & İndirilen Cam Küreciklerinin Dolum Yerine Getirilmesi & \\
\hline Yöntemin Adı & Değerlendirme Sonucu & Risk Yüzdesi \\
\hline OWAS & $\begin{array}{l}\text { Çalışanın kas iskelet sistemine etki eden bir zorlanma durumu olmadığı için } \\
\text { düzenleme gerekli değildir. }\end{array}$ & $\% 25$ \\
\hline REBA & $\begin{array}{l}\text { Risk düzeyi orta olarak çıkmaktadır. Bu sonuca göre bu iş için iyileştirme } \\
\text { gereklidir. }\end{array}$ & $\% 27$ \\
\hline ManTRA & $\begin{array}{c}\text { Sırt, boyun/omuzlar, kol/bilek/el ve bacak bölgeleri için düzenleyici işlem } \\
\text { önceliği mevcuttur. }\end{array}$ & $\% 63$ \\
\hline
\end{tabular}

İndirilen cam küreciklerinin dolum yerine getirilmesi işinde en yüksek risk yüzdesini ManTRA vermekte olup, birikimli risk puanı 10 olarak hesaplanmıştır (Tablo 9). Bu sonuca göre çalışanın sırt, boyun/omuzlar, kol/bilek/el ve bacak bölgeleri için düzenleyici işlem önceliği mevcuttur sonucuna ulaşılmıştır. OWAS ve REBA yöntemlerinin risk yüzdeleri aynıdır. Fakat eylem düzeyiz açısından bakıldığında REBA yönteminde bu iş için iyileştirme gereklidir sonucunu vermektedir. Tüm yöntemlerden elde edilen sonuçlara bakılarak indirilen cam küreciklerinin dolum yerine getirilmesi işinde sırt, boyun/omuzlar, kol/bilek/el ve bacak bölgelerinde düzenleyici işlem gereklidir sonucuna varılmıştır.

Tablo 10. İs 8 İçin Yapılan Ergonomik Risk Değerlendirmesi Sonucu

\begin{tabular}{|c|c|c|}
\hline İșin Adı & Dolum Yerine Getirilen Cam Küreciği Çuvallarının Maket Bıçağı İle Ağzının A & \\
\hline Yöntemin Adı & Değerlendirme Sonucu & Risk Yüzdesi \\
\hline OWAS & $\begin{array}{c}\text { Çalışanın kas iskelet sistemine etki eden bir zorlanma durumu olmadığı için } \\
\text { düzenleme gerekli değildir. }\end{array}$ & $\% 25$ \\
\hline REBA & $\begin{array}{l}\text { Risk düzeyi orta olarak çıkmaktadır. Bu sonuca göre bu iş için iyileştirme } \\
\text { gereklidir. }\end{array}$ & $\% 27$ \\
\hline ManTRA & Düzenleyici işlem önceliği yoktur. & $\% 47$ \\
\hline
\end{tabular}

Dolum yerine getirilen cam küreciği çuvallarının maket bıçağı ile ağzının açılması işinde, Tablo 10’a göre ManTRA yöntemi risk yüzdesi bakımından en iyi sonucu vermektedir. ManTRA yöntemine göre bu iş için düzenleyici işlem önceliği yoktur. OWAS ve REBA yöntemleri risk yüzdesi bakımından incelendiğinde aynı sonucu vermektedir. OWAS yöntemi değerlendirmesi çalışanın kas iskelet sistemine etki eden bir zorlama durumu olmadığını ve düzenleme gerekli değildir sonucunu vermektedir. REBA yöntemi ise orta risk düzeyi ile bu iş için iyileştirme gereklidir sonucunu vermektedir. Tüm yöntemlerden elde edilen sonuçlar incelendiğinde bu iş için $\mathrm{kol} / \mathrm{bilek} / \mathrm{el}$ bölgesinde düzenleyici eylem gerekmektedir.

Tablo 11. İş 9 İçin Yapılan Ergonomik Risk Değerlendirmesi Sonucu

\begin{tabular}{c|c|c}
\hline İşin Adı & Ağzı Açılan Cam Küreciği Çuvallarının Çizgi Arabasına Dökülmesi İşi & Reğerlendirme Sonucu \\
\hline Yöntemin Adı & Çalı̧̧anın kas iskelet sistemine etki eden bir zorlanma durumu olmadığı için \\
düzenleme gerekli değildir. & $\% 25$ \\
\hline OWAS & Risk düzeyi orta olarak çımaktadır. Bu sonuca göre bu iş için iyileştirme \\
gereklidir. & $\% 40$ \\
\hline REBA & Boyun/omuzlar ve kol/bilek/el bölgelerinde düzenleyici işlem önceliği mevcuttur. & $\% 100$ \\
\hline ManTRA
\end{tabular}

Tablo 11'de verilen sonuçlara göre, ağzı açılan cam küreciği çuvallarının çizgi arabasına dökülmesi işinde risk yüzdesi bakımından en iyi sonucu ManTRA yöntemi vermektedir. Çaba risk puanı 5 olarak elde edilen ManTRA yöntemi sonucuna göre boyun /omuzlar ve kol/bilek/el bölgerinde düzenleyici işlem önceliği mevcuttur. İkinci olarak en iyi risk yüzdesini REBA yöntemi ayrıca en yüksek eylem seviyesi sonucunu vermektedir. Bu sonuca göre risk düzeyi orta olup iyileştirme gereklidir. OWAS yöntemi sonucunda ise çalışanın kas iskelet sistemine etki eden bir zorlama durumu olmadığı için düzenleme gerekli değildir. Tüm yöntemlerden elde edilen sonuçlara bakılarak bu iş için çalışanın kas iskelet sistemine etki eden bir zorlama durumu olduğu saptanmıştır. Sırt, Boyun/omuz ve kol/bilek/el bölgelerinde düzenleyici işlem önceliği mevcuttur.

Tablo 12. İş 10 İçin Yapılan Ergonomik Risk Değerlendirmesi Sonucu

\begin{tabular}{c|c|c}
\hline İşin Adı & Çizgi Arka Operatörünün Çizgi Aparat Direksiyonu İle Açma-Kapama Yapması İşi \\
\hline Yöntemin Adı & Değerlendirme Sonucu & Risk Yüzdesi \\
\hline OWAS & Çalışanın kas iskelet sistemine etki eden bir zorlanma durumu olmadığı için \\
düzenleme gerekli değildir. & $\% 25$ \\
\hline REBA & Risk düzeyi orta olarak çımaktadır. Bu sonuca göre bu iş için iyileştirme \\
gereklidir. & $\% 40$ \\
\hline ManTRA & Sirt ve kol/bilek/el bölgelerinde düzenleyici işlem önceliği mevcuttur. & $\% 00$ \\
\hline
\end{tabular}

Çizgi arka operatörünün çizgi aparat direksiyonu ile açma-kapama yapması işinde Tablo 12 incelendiğinden en yüksek risk yüzdesini ManTRA yöntemi vermektedir. Birikimli risk puanı 9 olarak hesaplanmıştır. Sonuç bakımından sırt ve kol/bilek/el 
bölgelerinde düzenleyici işlem önceliği mevcuttur sonucuna ulaşılmaktadır. Eylem seviyesi bakımından en iyi sonucu REBA yöntemi vermekte ve orta risk düzeyici ile bu iş için iyileştirme gereklidir sonucunu vermektedir. OWAS yöntemi hem risk yüzdesi hemde eylem seviyesi bakımından son sırada yer almaktadır. OWAS yöntemine göre çalışanın kas iskelet sistemine etki eden bir zorlama durumu olmadığı için iyileştirme gerekli değildir. Tüm yöntemlerden elde edilen sonuçlar incelendiğinde bu iş için sırt ve kol/bilek/el bölgesinde düzenleyici işlem gereklidir.

Tablo 13 incelendiğinde çizgi ön operatörünün çizgi arabasını sürmesi işinde risk yüzdesi bakımından en iyi sonucu ManTRA yöntemi vermektedir. ManTRA yöntemine göre bu iş için düzenleyici işlem önceliği yoktur. OWAS ve REBA yöntemlerinden elde edilen risk yüzdeleri aynı olmasında rağmen REBA yöntemi eylem seviyesi bakımından en yüksek sonucu vermektedir. Bu sonuca göre risk düzeyi orta çıkmakta ve bu iş için iyileştirme gereklidir sonucunu vermektedir. OWAS yöntemi ise eylem seviyesi bakımından bu iş için düzenleme gerekli değildir sonucunu vermektedir. Tüm yöntemlerden elde edilen sonuçlar incelendiğinde çizgi ön operatörünün çizgi arabasını sürmesi işinde sırt ve kol/bilek/el bölgesinde düzenleyici işlem gereklidir.

Tablo 13. İş 11 İçin Yapılan Ergonomik Risk Değerlendirmesi Sonucu

\begin{tabular}{|c|c|c|}
\hline İşin Adı & Çizgi Ön Operatörünün Çizgi Arabasını Sürmesi İşi & \\
\hline Yöntemin Adı & Değerlendirme Sonucu & Risk Yüzdesi \\
\hline OWAS & $\begin{array}{c}\text { Çalışanın kas iskelet sistemine etki eden bir zorlanma durumu olmadığ için } \\
\text { düzenleme gerekli değildir. }\end{array}$ & $\% 25$ \\
\hline REBA & $\begin{array}{l}\text { Risk düzeyi orta olarak çıkmaktadır. Bu sonuca göre bu iş için iyileştirme } \\
\text { gereklidir. }\end{array}$ & $\% 27$ \\
\hline ManTRA & Düzenleyici işlem önceliği yoktur. & $\% 53$ \\
\hline
\end{tabular}

Tablo 14. İş 12 İçin Yapılan Ergonomik Risk Değerlendirmesi Sonucu

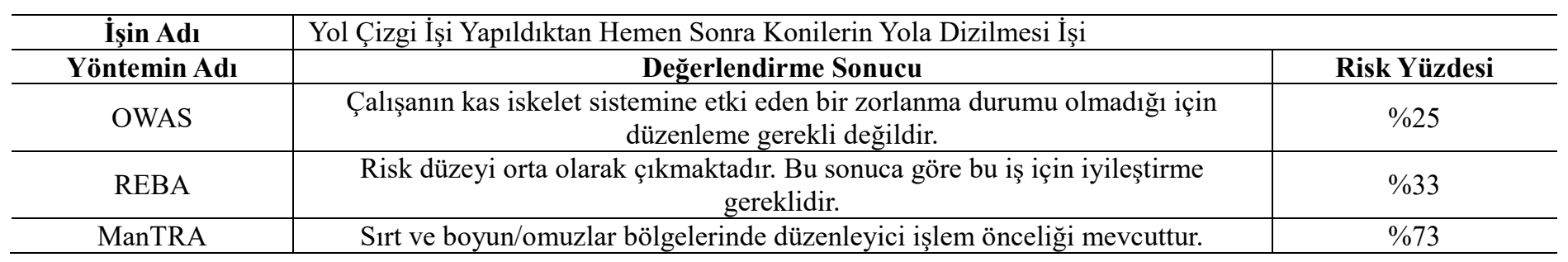

Yol çizgi işi yapıldıktan hemen sonra konilerin yola dizilmesi işinde, risk yüzdesi bakımından en iyi sonucu ManTRA yöntemi vermektedir (Tablo 14). Birikimli risk puanı 11 olarak hesaplanan ManTRA yöntemi sonucuna göre sirt ve boyun/omuzlar bölgelerinde düzenleyici işlem önceliği mevcuttur. REBA ve OWAS yöntemi risk yüzdeleri birbirine çok yakın sonuçlar vermektedir. Eylem seviyesi bakımından en iyi sonucu REBA yöntemi vermiştir. Sonuca göre risk düzeyi orta çıkmakta ve bu iş için düzenleyici işlem gereklidir. OWAS yöntemi hem risk yüzdesi hemde eylem seviyesi bakımından son sıradadır. OWAS yöntemine göre çalışanın kas iskelet sistemine etki eden bir zorlama durumu olmadığı için düzenleme gerekli değildir. Tüm yöntemlerden elde edilen sonuçlar bakımından yol çizgi işi yapıldıktan hemen sonra konilerin yola dizilmesi işinde sırt, boyun/omuzlar ve kol/bilek/el bölgelerinde düzenleyici işlem gereklidir.

Tablo 15. İş 13 İçin Yapılan Ergonomik Risk Değerlendirmesi Sonucu

\begin{tabular}{|c|c|c|}
\hline İşin Adı & Yol Çizgi İşi Yapıldıktan Hemen Sonra Konilerin Geri Toplanması İşi & \\
\hline Yöntemin Adı & Değerlendirme Sonucu & Risk Yüzdesi \\
\hline OWAS & $\begin{array}{l}\text { Çalışanın kas iskelet sistemine zararlı etkilere neden olan az zorlanma durumu } \\
\text { olduğu için yakın bir zamanda düzenleme gerektirmektedir. }\end{array}$ & $\% 50$ \\
\hline REBA & $\begin{array}{l}\text { Risk düzeyi orta olarak çıkmaktadır. Bu sonuca göre bu iş için iyileştirme } \\
\text { gereklidir. }\end{array}$ & $\% 33$ \\
\hline ManTRA & $\begin{array}{l}\text { Sirt, boyun/omuzlar ve kol/bilek/el bölgelerinde düzenleyici işlem önceliği } \\
\text { mevcuttur. }\end{array}$ & $\% 73$ \\
\hline
\end{tabular}

Tablo 15 incelendiğinde yol çizgi işi yapıldıktan hemen sonra konilerin geri toplanması işinde en yüksek risk yüzdesini ManTRA yöntemi vermektedir. Birikimli risk puanı 11 olarak hesaplanan bu iş için sırt, boyun/omuzlar ve kol/bilek/el bölgelerinde düzenleyici işlem önceliği mevcuttur sonucu elde edilmiştir. Eylem seviyesi bakımından OWAS ve REBA yöntemleri benzer sonucu vermektedir. OWAS yöntemi sonucunda çalışanın kas iskelet sistemine zararlı etkilere neden olan zorlanma durumu olduğu için yakın zamanda düzenleme gereklidir sonucuna ulaşılmıştır. Yine REBA yöntemi sonucunda risk düzeyi orta çıkmakta ve bu iş için düzenleyici işlem gerekmektedir sonucunu vermektedir. Tüm yöntemler birlikte değerlendirlmdiğinde, çalışanın kas iskelet sistemine etki eden bir zorlama durumu olduğundan yakın bir zamanda sırt, boyun/omuzlar ve kol/bilek/el bölgelerinde düzenleyici işlem gerektiği sonucuna ulaşılmaktadır.

Yol inşaatı şantiyelerinde, ince işlerden yol çizgisi yapım işinde çalışanlar için yapılan ergonomik risk değerlendirmesi sonuçları aşağıda verilmektedir; 
- İkmal yapılacak boya tenekesinin istif yerinden indirilmesi işi çalışanın kas iskelet sistemine zararlı etkilere neden olmaktadır. Çalışanın bu işi yaparken en fazla etkilenen vücut bölümlerinin sırt, boyun/omuz, kol/bilek/el ve bacak bölgelerinde olduğu belirlenmiştir. $\mathrm{Bu}$ iş ile ilgili yakın bir zamanda düzenleyici işlem yapılması gerekmektedir.

- İndirilen boya tenekesinin dolum yerine getirilmesi işi çalışanın kas iskelet sistemine zararlı etkilere neden olmaktadır. Çalışanın bu işi yaparken en fazla etkilenen vücut bölümlerinden sırt, boyun/omuzlar ve kol/bilek/el bölgelerinde olup bu iş için iyileştirme gereklidir.

- Dolum yapılacak tenekenin ağzının spatula ile açılması işinde çalışanın kas iskelet sistemine zararlı etki eden durumların olduğu ve vücudun bölümlerinden sırt, boyun/omuz, kol/bilek/el ve bacak bölgelerinde yakın bir zamanda düzenleyici işlem yapılması gerekmektedir.

- Ağzı açılan tenekedeki boyanın mikser ile karıştırılması işinde çalışanın kas iskelet sistemine etki eden zorlama durumları olduğu saptanmıştır. Çalışanın sırt, boyun/omuz ve kol/bilek/el bilek bölgelerinde yakın bir zamanda düzenleyici eylem gerekmektedir.

- Mikser ile karıştırılan boyanın ikmal kazanına dökülmesi işinde çalışanın kas iskelet sistemine etki eden bir zorlanma durumu olmaktadır. Çalışanın sırt, boyun/omuzlar ve kol/bilek/el bölgelerinde düzenleyici eylem gerekmektedir.

- Cam küreciklerinin istif yerinden indirilmesi işinde elde edilen sonuçlar incelendiğinde ise çalışanın sırt ve kol/bilek/el bölgesinde düzenleyici işlem gerekmektedir.

- İndirilen cam küreciklerinin dolum yerine getirilmesi işinde elde edilen sonuçlara bakılarak çalşanın sırt, boyun/omuzlar, $\mathrm{kol} / \mathrm{bilek} / \mathrm{el}$ ve bacak bölgelerinde düzenleyici işlem gerekmektedir.

- Dolum yerine getirilen cam küreciği çuvallarının maket bıçağı ile ağzının açılması işinde yöntemlerden elde edilen sonuçlar incelendiğinde çalışanın vücut bölümlerinden kol/bilek/el bölgesinde düzenleyici eylem gerekmektedir.

- Ağzı açılan cam küreciği çuvallarının çizgi arabasına dökülmesi işinde elde edilen sonuçlara bakılarak çalışanın kas iskelet sistemine etki eden bir zorlama durumu olduğu saptanmıştır. Sırt, boyun/omuz ve kol/bilek/el bölgelerinde düzenleyici işlem önceliği mevcuttur.

- Çizgi arka operatörünün çizgi aparat direksiyonu ile açma-kapama yapması işinde edilen sonuçlar incelendiğinde çalışanın vücudun bölümlerinden sirt ve kol/bilek/el bölgesinde düzenleyici işlem gerekmektedir.

- Çizgi ön operatörünün çizgi arabasını sürmesi işinde elde edilen sonuçlar incelendiğinde çalışanınvücut bölümlerinden sırt ve $\mathrm{kol} / \mathrm{bilek} / \mathrm{el}$ bölgesinde düzenleyici işlem gerekmektedir.

- Yol çizgi işi yapıldıktan hemen sonra konilerin yola dizilmesi işinde elde edilen sonuçlar bakımından çalışanın vücut bölümlerinden sırt, boyun/omuzlar ve kol/bilek/el bölgelerinde düzenleyici işlem gerekmektedir.

- Yol çizgi işi yapıldıktan hemen sonra konilerin geri toplanması işinde elde edilen sonuçlar ile birlikte çalışanın kas iskelet sistemine etki eden bir zorlama durumu olduğundan yakın bir zaman vücudun bölümlerinden sırt, boyun/omuzlar ve kol/bilek/el bölgelerinde düzenleyici işlem gerekmektedir.

Uygulanan yöntemler ayrı ayrı değerlendirildiğinde ise aşağıdaki sonuçlar elde edilmiştir;

- OWAS yöntemi için; 9 işin kas iskelet sistemine zararlı etkileri olmadığı ve düzenleme gerektirmediği, 2 işin kas iskelet sistemine bazı zararlı etkileri olduğu ve düzenlemenin yakın bir zamanda yapılması gerektiği, 2 işin kas iskelet sistemine zararlı etkilerinin olduğu ve düzenlemenin en kısa zamanda yapılması gerektiği sonucunu vermiştir.

- REBA yöntemi için; 1 işin risk düzeyinin düşük olduğu ve düzenleme yapılması gerekebilir, 11 işin risk düzeyinin orta olduğu ve düzenleme yapılması gerektiği, 1 işin yüksek riski olduğu ve düzenlemenin yakın zamanda yapılması gerektiği sonucunu vermiş̧ir.

- ManTRA yöntemi için; 3 iş için eylem önceliği yok iken 2 iş için sırt, boyun/omuzlar, kol/bilek/el ve bacak bölgesinde, 2 iş için sırt ve kol/bilek/el bölgesinde, 4 iş için sırt, boyun/omuzlar ve kol/bilek/el bölgesinde, 1 iş için sirt ve boyun/omuzlar bölgesinde, 1 iş için boyun/omuzlar ve kol/bilek/ el bölgesinde eylem önceliği mevcuttur sonucunu vermiş̧ir.

Ergonomik risk değerlendirmesinde kullanılan yöntemler ve verdiği sonuçlar incelendiğinde ManTRA yöntemi en yüksek risk yüzdesini vermektedir. ManTRA yönteminin risk yüzdesi bakımından en yüksek sonucu vermesinin nedeni kuvvet ve kuvvet uygulama hızına dayalı olarak elde edilen çaba risk faktörü değerine göre de risk yüzdesinin belirlenebilmesidir. Ayrıca ManTRA yöntemi vücut bölümleri ile ilgili ayrıntılı değerlendirme sonuçları sağlamaktadır. Ama yapılan işin öncelik bakımından düzenleme yapılıp yapılmayacağı konusunda tek başına yeterli değildir. Diğer risk değerlendirme yöntemleri ile birlikte kullanıldığında işin risk düzeyini desteklemektedir. Eylem seviyesi açısından OWAS ve REBA yöntemlerin benzer sonuçlar elde edilmiştir. Risk değerlendirmenin temel amacına uygun olarak eylem seviyesi açısından en iyi sonucu OWAS ve REBA yöntemleri vermektedir. OWAS veya REBA yöntemi ile elde edilen eylem seviyesi ile birlikte ManTRA yönteminden elde edilen işlem önceliği birlikte kullanılarak vücudun odaklanılması gereken bölümü belirlenmektedir.

\section{Sonuç}

Yapılan ergonomik risk değerlendirmesi sonucunda yol çizgi çalışma ekibinde kas iskelet sisteminde zorlamaya neden olan işler belirlenmiştir. İncelenen işlerden birkaç tanesi dışında diğer tüm işlerde yakın zamanda iyileştirme yapılması gerektiği sonucuna ulaşılmıştır. Bu işlerde vücudun en çok zorlanan sırt, boyun/omuzlar, kol/bilek/el ve bacak bölgelerinde kas iskelet sistemi rahatsızlığına neden olacak durumlar sunulmuştur. Ergonomik risk değerlendirmesi sonucunda çalışan ile kullanılan uygun makine-araç arasındaki önem ortaya koyulmuştur. Çalışma şartlarının uygunluğu ve her türlü koruyucu önlemlerin alınması, hem meslek hastalıklarının minimum düzeye inmesine hemde çalışanların daha verimli üretimde bulunmalarını sağlayacaktır. Yapılan bu çalışmalar ekipte çalışma isteğini yükseltmekte ve çalışanların ergonomik riskler konusunda farkındalıklarını arttırmaktadır. 


\section{Kaynakça}

Akay, D.A. \& Dağdeviren, M. (2003). Çalışma Duruşlarının Ergonomik Analizi. Gazi Üniversitesi Mühendislik Mimarlık Fakültesi Dergisi, 18 (3), 73-84.

Aksöyek, A. R. (2002). Türk inşaat Sektöründe Işs Kazalarının ve İş Güvenliği Sorunun İncelenmesi, Yüksek Lisans Tezi, İstanbul Teknik Üniversitesi.

Atasoy Mert, E. (2014). Ergonomik Risk Değerlendirme Yöntemlerinin Karşılaşttrılması ve Bir Çanta İmalat Atölyesinde Uygulanması, İş Sağlı̆̆ı ve Güvenliği Uzmanlık Tezi, Çalışma ve Sosyal Güvenlik Bakanlığı İş Sağlığı ve Güvenliği Genel Müdürlüğü.

Corlett, N., Wilson, J., Manenica, I., (1985). The Ergonomics of Working Postures, International Occupational Ergonomics Symposium, s. 100-105, Zadar, Yugoslavya.

Erkan, N. (1997). Ergonomi Verimlilik, Sağlık ve Güvenlik İ̧̧in İnsan Faktörü Mühendisliği, Ankara: Milli Prodüktivite Merkezi Yayınları.

Gönenç, İ. G. (2016). Yol Şantiyelerinde ve Çevresinde İş Sağllğl ve Güvenliği Risklerinin Değerlendirmesi, İş Sağlığı ve Güvenliği Uzmanlık Tezi, Çalışma ve Sosyal Güvenlik Bakanlığı İs Sağlı̆̆ı ve Güvenliği Genel Müdürlüğü.

Hignett, S. \& McAtamney, L. (2000) Rapid entire body assessment (REBA). Applied Ergonomics, 31(2), 2015-205.

Kocabaş, M. (2009). Ağır ve Tehlikeli İşlerde Çalışan İş Görenlerde Zorlanmaya Neden Olan Çalışma Duruşlarının Analizi, Yüksek Lisans Tezi, Selçuk Üniversitesi.

Koç, S., Testik, Ö. M., (2016). Mobilya Sektöründe Yaşanan Kas-İskelet Sistemi Risklerinin Farklı Değerlendirme Metotları ile İncelenmesi ve Minimizasyonu, Endüstri Mühendisliği Dergisi, 2-27.

Kuruoğlu, M. Albayrak Kuruoğlu, Y. Sarı, A., Haznedaroğlu, F. (2015). Ergonomi ve Antropometri Alanındaki Çalışmaların İnşaat Sektöründeki Yeri ve İş Güvenliği Açısından Önemi, 5. İş̧̧i Sağllğı ve İ̧̧ Güvenliği Sempozyumu, İzmir, Türkiye.

Limerick, R.B. (2016). Further Risk Assessment Methods for Hazardous Manual Tasks. http://ergonomics.uq.edu.au/ download/mantra2.pdf adresinden alınd1, Erişim Tarihi: 18.12.2016.

Müngen, U. (2011). İnşaat Sektörümüzdeki Başlıca İş Kazası Tipleri. Türkiye Mühendis Haberleri, 2011(5), 469.

Özcan, E., Kesiktaş, N., (2007). Meslek Kas İskelet Hastalıklarından Korunma ve Ergonomi. İş Sağllğı ve Güvenliği Dergisi, Sayı:342007/7, Ankara, Türkiye.

Stanton, N., Hedge, A., Brookhuis, K., Salas, E., Hendrick, H. (2005). Handbook of Human Factors and Ergonomics Methods, Florida: CRC Press.

Yürek, K. (2018). Yol İnşaatı Şantiyelerinde Ergonomik Rsk Değerlendirmesi, Yüksek Lisans Tezi, Mersin Üniversitesi. 